\title{
Mono-ADP-Ribosyltransferase Sirtuin-6
}

National Cancer Institute

\section{Source}

National Cancer Institute. Mono-ADP-Ribosyltransferase Sirtuin-6. NCI Thesaurus. Code C82857.

Mono-ADP-ribosyltransferase sirtuin-6 (355 aa, $39 \mathrm{kDa}$ ) is encoded by the human SIRT 6 gene. This protein may be involved in post-translational protein modification. 